IJSSP

$41,13 / 14$

96

Received 24 September 2020 Revised 14 December 2020 12 January 2021

Accepted 14 January 2021

\section{Retirement pathways and pension inequality in China: a grounded theory study}

\author{
Qi Wang and Virpi Timonen \\ Trinity College Dublin, Dublin, Ireland
}

\begin{abstract}
Purpose - Existing research focuses on the pension systems and reforms in China from a macro-level and financial perspective. The expectations of mid-life Chinese people regarding their retirement and pensions have been ignored to date, and this research set out to address this lacuna.

Design/methodology/approach - The application of qualitative research methods is relatively novel in Chinese social science. As a grounded theory (GT) study, the research reported here deployed semi-structured interviews to investigate middle-aged Chinese women's and men's perceptions of their pensions and retirement. In total, 36 interviews were conducted, following the constructivist GT method.

Findings - The data point to disparities between the choices and perceptions of individuals on the one hand and the official assumptions underlying the current pension regime on the other hand. Research participants had varying interpretations of the inequality in retirement incomes in China, the main division being between enterprise workers and public-sector employees.

Originality/value - Although there are in principle rigidly fixed retirement ages for men and women in contemporary China, the phenomena of early retirement and working post-retirement are increasing. There are trade-offs between work/retirement and family needs, which influence the choices of middle-aged citizens. Retirement pathways are increasingly individualised, reflecting broader patterns of individualisation and inequality in China.
\end{abstract}

Keywords Ageing, China, Pensions, Retirement, Grounded theory

Paper type Research paper

\section{Introduction}

With the ageing of the Chinese population, questions regarding pensions and retirement in contemporary China have drawn the attention of scholars around the world, with a distinct focus on systemic and economic issues (Feldstein, 1999; Beland and Yu, 2004; Frazier, 2004; Cai and Cheng, 2014; Song et al., 2015). Consequently, we know little about how Chinese people view their retirement prospects, what they think about the pension regime and how they negotiate work and family considerations in planning for retirement. Focussing on middle-aged people in present-day urban China, this article elucidates their experiences, expectations and concerns regarding pensions and pathways to retirement. Given that qualitative social research on the middle-aged population in China has been minimal, this article contributes to filling a gap in understanding the pathways to retirement and views of the current pension regime in China. Considering the paucity of knowledge on this topic, the grounded theory (GT) approach was chosen to guide this study, and semistructured interviews were selected as the research method. In keeping with the GT method

(C) Qi Wang and Virpi Timonen. Published by Emerald Publishing Limited. This article is published under the Creative Commons Attribution (CCBY 4.0) licence. Anyone may reproduce, distribute, translate and create derivative works of this article (for both commercial and non-commercial purposes), subject to full attribution to the original publication and authors. The full terms of this licence may be seen at http://creativecommons.org/licences/by/4.0/legalcode

The authors are grateful to the research participants for their time and contributions to this study. Qi Wang received a PhD scholarship from the School of Social Work and Social Policy at Trinity College Dublin while conducting this research.
International Journal of Sociology and Social Policy Vol. 41 No. 13/14, 2021 pp. 96-111 Emerald Publishing Limited 0144-333X

DOI 10.1108/IJSSP-09-2020-0454 
(Timonen et al., 2018), our research proceeded in the absence of an overarching theoretical framework and took an inductive approach for understanding the lived experiences of midlife individuals. To contextualise our findings, we offer some background information and sensitising concepts in the next section.
Retirement pathways and pension inequality

\section{Background}

China introduced a communist pension system after 1949. Working units contributed three per cent of the payroll, but this form of welfare only covered a few sectors (Zhang, 2009). In the "Cultural Revolution" between 1966 and 1976, this pension policy was interrupted and was followed by a period of economic reform. Since the 1970s, pension reforms in China have been aligned with the gradual movement towards a market-oriented economy (West, 1999). Employers and employees have been required to make contributions to the pension system since the 1980s, with the employers' share outweighing employee contributions by a large margin (Salditt et al., 2008). Following decreases in the burden on enterprises, the contributions are now $20 \%$ for enterprises and $8 \%$ for employees (Salditt et al., 2008). The coverage of pensions in China expanded dramatically with the creation of pension schemes for rural dwellers and those urban residents who previously were not covered by pension schemes for workers (e.g. the unemployed) (Liu and Sun, 2016). As a result, most individuals in China now have an entitlement to a pension. However, the pensions for rural dwellers and urban unemployed citizens are extremely low, with basic amounts of around nine dollars per month (Liu and Sun, 2016).

In addition to the pension scheme for enterprise workers, rural residents and urban dwellers who are not employed, there were two independent schemes for public officials and the members of public institutions. "Federal officials" is a term that refers to the staff of various levels of government, while members of the public institutions are those who work for the other parts of the establishment such as schools, colleges, hospitals, media and other agencies that are controlled by the Chinese Communist Party (CCP). There used to be five independent pension schemes in China. However, the separate pension schemes for public officials and state institutions were abolished in 2015 (Liu and Sun, 2016). These two schemes were considered to be unfair because the members did not need to contribute to the systems, yet they could receive pensions that had higher replacement rates than the pensions for enterprise workers. After the reform, staff at public institutions had to make contributions on terms similar to those of enterprise workers (Liu and Sun, 2016). However, in terms of pension entitlements, the gap between enterprise workers and public-sector employees remains large. The implications of this will be interrogated in the findings.

The one-child policy, introduced in 1979, has had a significant influence on the structure of Chinese families although it has been argued that " $t$ ]he most dramatic decrease in the [fertility] rate actually occurred before the policy was imposed" (Hesketh et al., 2005, p. 1172). The stringent one-child policy resulted in rapid ageing of the Chinese population and increased dependency ratios (Hu and Yang, 2012). Most of the participants in this research were typical of their cohort in urban contexts in that they have one child. Due to the relatively small number of adult children available to support their ageing parents, older people have come to rely more on themselves, e.g. by making provision for formal care arrangements. Furthermore, expectations on adult children as care providers are now considerably lower than in the past (Eklund, 2018). As neither family support nor the pension and care systems are meeting the needs of all older adults, income security and care poverty in later lives are growing concerns.

To supplement Western-centric welfare regimes (most notably Esping-Andersen, 1990), authors such as Jones (1993) have proposed the notion of "Confucian welfare state" to describe East Asian welfare. According to Abrahamson (2017), the term Confucian welfare state should also be applied to China. Although research on East Asian welfare systems partly abandoned the Confucian label in the 2000s, there is a revival of discussions on the Confucian welfare state 
IJSSP

$41,13 / 14$

\section{8}

in recent years (Abrahamson, 2017). The main feature of the Confucian welfare state is the vital importance of family in providing social care and the low level of governmental involvement in welfare provision (Bambra, 2007). East Asian cultures traditionally viewed children as private assets and family responsibility as extending to care of their young and old members (Lin and Rantalaiho, 2003). In China, care is still primarily delivered by family members, and the role of the state in care provision remains limited (Zhu and Walker, 2017).

Holliday (2000) focused on the productivist character of the East Asian welfare regime, and Kwon (2005) proposed the description of "developmental welfare state". Both studies argue that social welfare serves the purpose of economic development, which results in the relatively modest welfare provision in East Asian countries (Abrahamson, 2017). However, Fisher and colleagues (2018) found that Shanghai has developed aged care services which are in many respects similar to those in Western developed countries; they argue that the differences in systems should be attributed to (regional) developmental stage instead of Confucianism. Also, some researchers have pointed to changes of familism in East Asia in recent years. For instance, Lee (2018) argues that there is evidence of transition from Confucian familism towards neo-familism. Neo-familism is a combination of conventional Confucianism and a new trend towards more equal relations between family members (Lee, 2018). The one-child policy is one of the factors that is driving the greater equality of relations. The one-child policy not only resulted in the imbalance in sex ratios (Ding and Hesketh, 2006) but it also contributed for improving the situation of women in China: as many girls became the only child in the family and more mothers could go to work due to the decrease in the number of children, the emphasis on the patrilineal and highly gendered traditions was lessened (Fong, 2002). Despite their improved position, majority of women are inclined to believe that the well-being of the family should be prioritised over the well-being of individuals (Chang and Song, 2010), an illustration of the limited prevalence of individualism in China.

Hinrichs and Lynch (2010) divided the pension systems in the Western world into "Bismarckian" and "Beveridgean" types. The Bismarckian approach is occupational or employment centred, focussing on the maintenance of status after retirement. This approach underpins pension systems in much of the continental Europe, Southern Europe, the USA and some countries (Sweden, Finland, Norway and Canada) veered towards this approach since the 1960s (Hinrichs and Lynch, 2010). In contrast, Beveridgean universal flat-rate pensions formed the basis of the pension systems in many Anglo-Saxon nations (except the USA) (Hinrichs and Lynch, 2010). Yeh et al. (2020) divide the East Asian pension systems into statist (mainland China and Taiwan), individualist (Hong Kong and Singapore) and dualist (Japan and Korea). China has a minimum contribution-based pension scheme as the first tier, and a public funded defined contribution/notional defined contribution pension as the second tier (OECD, 2017). The Mercer report (2019) assessed 37 pension regimes based on three principles: adequacy (benefits, system design, savings, tax support, home ownership and growth assets), sustainability (pension coverage, total assets, contributions, demography, government debt and economic growth) and integrity (regulation, governance, protection, communication and operating costs). According to their assessment, the Chinese pension regime was given a grade D (along with Korea, Japan, India, Mexico, Philippines, Turkey, Argentina and Thailand). The pension regime of China is considered to have major weaknesses, especially in sustainability and integrity (Mercer, 2019).

Income inequality and consumption inequality among older people in China are comparatively high (Bakkeli, 2020). Considering the contribution of pensions towards total household incomes, such contribution is much higher in urban China (nearly $80 \%$ ) compared with rural China (2\%) (Prince et al., 2016). This figure illustrates the inequality in pensions between urban and rural China, as well as differences in household composition. There are also significant gender differences. The official retirement ages in China are 60 for men, 55 for white collar women and 50 for blue collar women (OECD, 2019). Considering the average life 
expectancy at birth is 76.7, these retirement ages are rather low, especially for women (OECD, 2019). We positioned our enquiry in this context of significant societal transformations, and a pension system that has not fully responded to changes in society and economy, asking: what are the perceptions of middle-aged adults in China in relation the pensions system and their expectations regarding retirement pathways?

\section{Methods}

Because of the paucity of literature on the experiences and opinions of the Chinese population regarding their retirement pathways and the pension system, the GT method was selected as the approach that best fits the purpose when broaching poorly-understood social patterns and processes. We chose the constructivist GT approach (Charmaz, 2014), where research is understood to be co-constructed by the researcher(s) and the research participants, "highlight [ing] the flexibility of the method and resist[ing] mechanical applications of it" (Charmaz, 2014, p. 13).

GT excels at generating new knowledge (Goulding, 1999). It is particularly suitable when knowledge is inadequate in some area (Flick, 2018). However, it is not necessary to ignore the existing literature before entering the field of research. In fact, only by reviewing relevant literature the researcher can identify the rationale for the research among the existing knowledge (Timmermans and Tavory, 2012). Therefore, we reviewed relevant literature before conducting fieldwork and as pointed out above, identified individual experiences and understandings of the pension systems and retirement pathways among middle-aged persons as a novel topic that has not been investigated and reported on in the Chinese context prior to our study.

Semi-structured interviews were chosen as the data collection tool. While this was deemed the most suitable method for generating data about perceptions and experiences of pensions and retirement, organising and conducting interviews in China presented a number of challenges. The qualitative interview method and findings of qualitative studies are not something that the vast majority of the population in China are familiar with. Social trust can be very low among some groups, and the research had to be proceeded accordingly. Hence, the starting point was snowballing out from individuals personally known to the researcher who carried out the interviews (Wang). Once these participants had been through the interview process, they felt more comfortable referring other participants to the study. Nonetheless, in order to widen the sample, it was necessary to take steps to recruit individuals outside the field researcher's personal networks, and this task called for considerable efforts in establishing his/her credentials, generating trust and assuring anonymity. However, we admit that we were unable and unwilling to entice people with the most trenchant critique of the system to take part in recorded interviews; indeed, this is a challenge that could not overcome in an ethical manner in China, as expressing strong anti-regime opinions can have severe consequences. Nonetheless, we were able to elicit a range of opinions, expectations and pathways in a context where qualitative research is emergent.

Theoretical sampling in GT necessitates identifying emergent patterns and discoveries in the data, and this was accomplished by two tranches of interviews. The first tranche of interviews started in January 2018 and ended in August 2018, i.e. this first phase of data collection lasted around eight months. There were two significant steps in this process. The first step was trying to achieve a degree of heterogeneity in the sample, including participants with different employment statuses and life experiences, and from different urban regions. Of course, this being qualitative research, we did not strive for representativeness of the extremely diverse population of China; rather, the purpose was to start off with a reasonably diverse group of participants, whose views and experiences could be investigated in depth. Concepts emerged after completing the data analysis. Based on these emerging concepts, the
Retirement pathways and pension inequality 
IJSSP

$41,13 / 14$ subsequent interviews were more targeted, in line with theoretical sampling, which is a key tenet of the GT method (Conlon et al., 2020).

One important group for theoretical sampling in the second stage of the first phase (from May to August 2018) comprised individuals who do not have a definite retirement date such as shop owners. Considering that most of the previous interviewees were either already retired or had a specific retirement age, more people without definite retirement plans were targeted. Most of these respondents were people who have their own businesses. Comparing the information provided by those who do not have a specific retirement age with the stories of the earlier participants yielded further insights.

Most of the respondents from these earlier fieldwork stages were middle-class, including teachers, managers, shop owners and so on. These participants were either covered by the pension scheme for public institutions with relatively adequate pension entitlements, or they were in enterprises which can guarantee sufficient retirement incomes for the employees. Thus, at the first stage of fieldwork, there was an insufficient insight into the experiences of working-class participants or those with low incomes. Working-class participants with lower incomes were targeted at the second stage of sampling. Understanding their plans, whether they planned to keep working after retirement, and the effects of low income on their retirement decisions were necessary for broader understanding of the retirement experiences and expectations in China.

In terms of the perspectives of the urban middle-aged Chinese people on pensions, different degrees of desire for greater equality were evident in the accounts of many participants. However, the critique of those who criticise the current arrangements also occurred in some interviews. In the next step, we sought to understand nuances of these contrasting viewpoints. Participants' views on a market-oriented pension reform also called for further elucidation at this stage of fieldwork; some agreed with it while others had concerns over the process of privatising pension schemes. This stage of theoretical sampling was challenging because it was not possible to establish potential interviewees' opinions towards pensions before interviewing them. However, more targeted questions were asked during this stage: the views that had been expressed by the earlier research participants were cited in the questions posed during subsequent interviews, so that we could get obtain further data to improve our understanding of views on this topic.

The second tranche of interviews started from January 2019 and ended in March 2019, in continuation of the theoretical sampling process. After the first round of interviews, two broad topic areas emerged throughout the interviews, pertaining to stances towards policy and retirement intentions. In order to look for the links between these two areas, the second tranche of interviews sought to gain a better understanding of the interconnectedness between these domains. Furthermore, follow-up interviews were conducted with two participants in order to "member check" our analysis of the relationships between key concepts.

The resulting sample composition is diverse within the limits of a single qualitative research project. As stated in the Introduction, middle-aged participants were targeted, since middle age being defined as "the period between early adulthood and old age, usually considered as the years from about 45 to 65" (Oxford English Dictionary, 2017). Considering the official retirement ages in China, which are 60 for men and 55 or 50 for women, 45 to 65 would be rather high in the Chinese context. Hence, we sampled for people who are facing transitions from employment to retirement currently or in the near future. Most of the participants were aged between 40 and 60 at the time of the interview, as outlined in Table 1 below, which also presents other key participant characteristics, including their household composition.

This research has some limitations. We did not set out to generate a representative sample, and the findings cannot be generalised to the middle-aged population of China, which is extremely diverse. Most interviews took place in Langfang, Hebei province, but 11 respondents were interviewed in other regions including Shanghai, Jiangsu, Hubei, Shandong 


\begin{tabular}{|c|c|c|c|c|c|c|c|}
\hline $\begin{array}{l}\text { Interview } \\
\text { number and } \\
\text { pseudonym }\end{array}$ & Gender & $\begin{array}{l}\text { Place of } \\
\text { residence }\end{array}$ & Employment status & Age & Interview setting & $\begin{array}{l}\text { Household/ } \\
\text { family status }\end{array}$ & $\begin{array}{r}\text { Retirement } \\
\text { pathways and } \\
\text { pension }\end{array}$ \\
\hline 1 Yaping & $\mathrm{F}$ & Hebei & $\begin{array}{l}\text { Teacher in primary } \\
\text { school }\end{array}$ & 50 & Private residence & $\begin{array}{l}\text { Living as a } \\
\text { couple }\end{array}$ & inequality \\
\hline 2 Zilin & $\mathrm{F}$ & Hebei & Teacher in college & 55 & Private residence & $\begin{array}{l}\text { Living as a } \\
\text { couple }\end{array}$ & 101 \\
\hline 3 Jialing & $\mathrm{F}$ & Hebei & Teacher in college & 55 & Private residence & Living alone & \\
\hline 4 Qinhong & $\mathrm{F}$ & Hebei & $\begin{array}{l}\text { Retired enterprise } \\
\text { worker }\end{array}$ & 48 & Private Residence & $\begin{array}{l}\text { Living as a } \\
\text { couple }\end{array}$ & \\
\hline 5 Zuyin & $\mathrm{F}$ & Hebei & Teacher in college & 53 & Private residence & $\begin{array}{l}\text { Living with } \\
\text { an adult child }\end{array}$ & \\
\hline 6 Shuzhi & $\mathrm{F}$ & Hebei & $\begin{array}{l}\text { Manager in medical } \\
\text { enterprise }\end{array}$ & 38 & $\begin{array}{l}\text { Meeting room of } \\
\text { the enterprise }\end{array}$ & $\begin{array}{l}\text { Living with } \\
\text { an adolescent } \\
\text { child }\end{array}$ & \\
\hline 7 Chunxian & M & Hebei & Shop owner & 43 & $\begin{array}{l}\text { Shop (quiet and no } \\
\text { customers) }\end{array}$ & $\begin{array}{l}\text { Living with } \\
\text { an adolescent } \\
\text { child }\end{array}$ & \\
\hline 8 Guofeng & M & Hebei & Doctor & 53 & $\begin{array}{l}\text { The participant's } \\
\text { living room }\end{array}$ & $\begin{array}{l}\text { Living as a } \\
\text { couple }\end{array}$ & \\
\hline 9 Baocai & $\mathrm{M}$ & Hebei & $\begin{array}{l}\text { Public official } \\
\text { (retired but went } \\
\text { back to work) }\end{array}$ & 63 & $\begin{array}{l}\text { Office of the } \\
\text { governmental } \\
\text { building }\end{array}$ & $\begin{array}{l}\text { Living as a } \\
\text { couple }\end{array}$ & \\
\hline 10 Qinlin & M & Hebei & $\begin{array}{l}\text { Public official } \\
\text { (retired but went } \\
\text { back to work) }\end{array}$ & 64 & $\begin{array}{l}\text { Office of the } \\
\text { governmental } \\
\text { building }\end{array}$ & $\begin{array}{l}\text { Living as a } \\
\text { couple }\end{array}$ & \\
\hline 11 Zexi & $\mathrm{M}$ & Hebei & $\begin{array}{l}\text { Public official } \\
\text { (retired but went } \\
\text { back to work) }\end{array}$ & 64 & $\begin{array}{l}\text { Office of the } \\
\text { governmental } \\
\text { building }\end{array}$ & $\begin{array}{l}\text { Living as a } \\
\text { couple }\end{array}$ & \\
\hline 12 Lianyu & M & Shanghai & $\begin{array}{l}\text { Retired enterprise } \\
\text { worker }\end{array}$ & 55 & Starbucks & $\begin{array}{l}\text { Living with } \\
\text { an adult child }\end{array}$ & \\
\hline 13 Shuli & $\mathrm{F}$ & Jiangsu & $\begin{array}{l}\text { Administrative } \\
\text { worker of a hospital }\end{array}$ & 54 & Café & $\begin{array}{l}\text { Living as a } \\
\text { couple }\end{array}$ & \\
\hline 14 Baosheng & M & Jiangsu & Professor & 48 & Audio talk online & $\begin{array}{l}\text { Living with } \\
\text { an adolescent } \\
\text { child }\end{array}$ & \\
\hline 15 Ping & M & Hubei & $\begin{array}{l}\text { Security staff } \\
\text { (coming back to } \\
\text { work) }\end{array}$ & 65 & Office & $\begin{array}{l}\text { Living as a } \\
\text { couple }\end{array}$ & \\
\hline 16 Longping & M & Hubei & Security staff & 58 & $\begin{array}{l}\text { Home of the } \\
\text { participant }\end{array}$ & $\begin{array}{l}\text { Living with } \\
\text { an adult child }\end{array}$ & \\
\hline 17 Liyan & $\mathrm{F}$ & Hebei & Shop owner & 47 & Café & $\begin{array}{l}\text { Living as a } \\
\text { couple }\end{array}$ & \\
\hline 18 Wengu & M & Shandong & $\begin{array}{l}\text { Manager of an } \\
\text { enterprise }\end{array}$ & 49 & Private residence & Living alone & \\
\hline 19 Caihu & M & Shandong & $\begin{array}{l}\text { Manager of an } \\
\text { enterprise }\end{array}$ & 45 & Private residence & Living alone & \\
\hline 20 Wenhua & $\mathrm{F}$ & Hebei & Shop owner & 53 & Café & $\begin{array}{l}\text { Living as a } \\
\text { couple }\end{array}$ & \\
\hline 21 Wanying & $\mathrm{F}$ & Hebei & $\begin{array}{l}\text { Retired enterprise } \\
\text { worker }\end{array}$ & 63 & $\begin{array}{l}\text { Neighbourhood } \\
\text { garden }\end{array}$ & $\begin{array}{l}\text { Living with } \\
\text { an adult child }\end{array}$ & \\
\hline 22 Yongqing & $\mathrm{F}$ & Hebei & Retired teacher & 63 & $\begin{array}{l}\text { Neighbourhood } \\
\text { garden }\end{array}$ & $\begin{array}{l}\text { Living with } \\
\text { an adult child }\end{array}$ & \\
\hline 23 Huibo & M & Hebei & Baker & 50 & $\begin{array}{l}\text { Roadside, under a } \\
\text { tree }\end{array}$ & (continued) & $\begin{array}{r}\text { Table 1. } \\
\text { Sample composition } \\
\text { and key characteristics }\end{array}$ \\
\hline
\end{tabular}




\begin{tabular}{|c|c|c|c|c|c|c|c|}
\hline \multirow[b]{2}{*}{$\begin{array}{l}\text { IJSSP } \\
41,13 / 14\end{array}$} & & & & \\
\hline & $\begin{array}{l}\text { Interview } \\
\text { number and } \\
\text { pseudonym }\end{array}$ & Gender & $\begin{array}{l}\text { Place of } \\
\text { residence }\end{array}$ & Employment status & Age & Interview setting & $\begin{array}{l}\text { Household/ } \\
\text { family status }\end{array}$ \\
\hline \multirow[b]{2}{*}{102} & $24 \mathrm{Xu}$ & M & Hebei & Safety supervision & 58 & $\begin{array}{l}\text { Neighbourhood } \\
\text { garden }\end{array}$ & \multirow{4}{*}{$\begin{array}{l}\text { Living with } \\
\text { an adult child } \\
\text { Living with } \\
\text { an adult child } \\
\text { Living with } \\
\text { an adult child } \\
\text { Living as a } \\
\text { couple }\end{array}$} \\
\hline & \multirow{2}{*}{26 Lizhi } & $\mathrm{F}$ & \multirow{2}{*}{ Hebei } & Housewife & 53 & & \\
\hline & & M & & Driver & 60 & $\begin{array}{l}\text { living room } \\
\text { Office }\end{array}$ & \\
\hline & 27 Zeming & M & Hebei & Warehouse keeper & 68 & Warehouse & \\
\hline & 28 Xueyan & $\mathrm{F}$ & Hebei & Shop owner & 40 & Tea shop & $\begin{array}{l}\text { Living with } \\
\text { an adolescent } \\
\text { child }\end{array}$ \\
\hline & $\begin{array}{l}29 \text { Zhaodi } \\
30 \text { Liyan } \\
31 \text { Huibo }\end{array}$ & $\begin{array}{l}\mathrm{F} \\
\text { see } 17 \\
\text { see } 23\end{array}$ & Hebei & Chef & 44 & $\begin{array}{l}\text { Café } \\
\text { Café } \\
\text { Café }\end{array}$ & Living alone \\
\hline & 32 Chaoting & M & Hebei & Cleaner & 63 & $\begin{array}{l}\text { Empty dance } \\
\text { studio }\end{array}$ & $\begin{array}{l}\text { Living with } \\
\text { an adult child }\end{array}$ \\
\hline & 33 Geng & M & Sichuan & $\begin{array}{l}\text { Teacher in } \\
\text { secondary school }\end{array}$ & 51 & $\begin{array}{l}\text { The participant's } \\
\text { living room }\end{array}$ & $\begin{array}{l}\text { Living with } \\
\text { an adolescent } \\
\text { child }\end{array}$ \\
\hline & 34 Rui & $\mathrm{F}$ & Sichuan & Statistician & 40 & $\begin{array}{l}\text { The participant's } \\
\text { living room }\end{array}$ & $\begin{array}{l}\text { Living with } \\
\text { an adolescent } \\
\text { child }\end{array}$ \\
\hline & 35 Jinya & $\mathrm{F}$ & Sichuan & Housewife & 50 & $\begin{array}{l}\text { The participant's } \\
\text { living room }\end{array}$ & Living alone \\
\hline Table 1. & 36 Jiangyan & $\mathrm{F}$ & Sichuan & $\begin{array}{l}\text { Retired factory } \\
\text { worker }\end{array}$ & 53 & Tea room & Living alone \\
\hline
\end{tabular}

and Sichuan. Although there is a degree of similarity between these areas (all are urban centres with high scores on human development index), they are comparatively high developed; hence, our findings have limited transferability to rural dwellers or to people who have tenuous connection to the social protection system (e.g. internal migrants).

The process of interviewee recruitment was not straightforward. Due to the social trust issue flagged above, some participants felt hesitant about filling in the ethics/consent form (which for them was reminiscent of bureaucracy and officialdom) before they had established a connection with the field researcher. The research had ethics approval from the Research Ethics Approval Committee of the School of Social Work and Social Policy, Trinity College Dublin and all key ethical tenets - voluntary informed consent, anonymity, confidentiality and non-malfeasance - were adhered to. Some (potential) participants voiced thoughts such as "I am not well educated/I am not a scholar, how can I contribute to a study?"; "you should find somebody who is more educated than I am"; "since we are in an interview, I do not think it is proper to speak this issue now" and similar sentiments indicative of feelings of inadequacy and caution. This demonstrates that the qualitative interview remains an unfamiliar practice in the Chinese context, especially among those who considered themselves "uneducated". This obstacle made our task more difficult compared to conducting fieldwork in contexts where qualitative interviews have been used for decades and where levels of trust are generally higher. Due to the path-breaking nature of this research project, it was more challenging to interact with potential participants who had these reservations and considerable time was spent assuring participants of their anonymity. Participants were 
given the opportunity to ask questions about the study and to read the information sheet in advance of the interview in order to ensure each person gave voluntary, informed consent. To protect the confidentiality of the interviewees, pseudonyms were assigned to replace the real names of the participants, and any potential identifying characteristics have been anonymised. However, doubtless the fact that the interviews were recorded deterred the most vocal critics from participating in this research, which is another acknowledgement but perhaps inevitable (in the Chinese context) limitation of this research.
Retirement pathways and pension inequality

\section{Findings}

The findings are divided into two sections; we will begin by examining attitudes towards the current pension system, before turning to the participants' choices and pathways towards work/retirement.

\section{Attitudes towards the current pension system}

The enterprise workers - who are entitled to relatively modest pensions - were generally dissatisfied with the current pension policy. They tended to think the pension policy in China is unfair:

What can you do with the [typical pension for enterprise workers] in our country? Perhaps just eat but not anything good. You cannot have anything else. If you are going to do some other things or [something unexpected] happens. . [the pension] will be absolutely inadequate. That is why we are so dissatisfied with it.

- Qinhong, female, 48, retired enterprise worker

The inequality between pension schemes and the low expectations regarding their pensions among enterprise workers put some of them under pressure to increase their retirement incomes: they felt compelled to find other ways to improve their economic security after retirement. For instance, Qinhong had found other work after retiring, and Xueyan focused on saving money for her retirement as well as purchasing commercial insurances. Xueyan had been an enterprise worker before leaving her working unit. She estimated that her pension would be around 3000 yuan [EUR 375] per month, amount that would not be sufficient for her living expenses in an urban area, especially if care needs were to arise, and this prospect was a concern for her:

...Do not speak of the future, for now, 3000 yuan will not be enough. I suppose, how to say, I will have to wait and see, right? So, I buy some commercial insurances when I can, I save as much money as possible while I still have the ability to do so. If you only rely on the pension, 3000 yuan, that will definitely not be enough.

- Xueyan, female, 40, shop owner

Divided by the pension schemes, the workers who are benefiting from the better pension schemes have a different view. For instance, when talking about the pension reform, Shuli stated that she wants her pension to remain unchanged and that she would be unhappy with any pension reform that decreased her retirement income. However, she also mentioned the pension gaps between different groups. Although the expectations and levels of satisfaction with the pension reform are diverse, even the relatively advantaged participants generally acknowledged that the pensions inequality between different social groups is a significant social problem. Shuli's response demonstrates both awareness of inequalities and inclination to accept them in order to protect one's own entitlements: 
IJSSP

$41,13 / 14$

104
I think I should be able to enjoy the relatively good policy. . .of course, the income gaps between enterprise workers and us [who work in] public institutions are relatively significant. . .but as for whether all the citizens can be treated the same, I think for China, with such a huge population, [pension inequalities] may not change in the future. . . Many things in China cannot be achieved in one step. It would be better if everyone received more. (. . .) [Pension reforms had] better not have any impact on me. Maintaining the current system would be good. . .I am relatively content.

- Shuli, female, 54, administrative worker in a hospital

As a public institution employee, Shuli's opinion stands in contrast to that of the enterprise workers such as Qinhong who was quoted above. Benefiting from relatively generous pension entitlements, Shuli expects to receive an adequate pension after retiring. Although she is aware of the inequality between different groups of workers, she knows that she has a vested interest in the current system. In other words, she realises that she is benefiting from an unfair pension system, which in turn makes her unwilling to accept major changes to current pension arrangements, especially when the changes may threaten her vested interest by weakening her pension entitlements.

The voice of Guofeng is also a contrast to that of Qinhong. Contrary to the frustration of Qinhong towards the current pension schemes, Guofeng criticised the actions of those who protest and campaign for greater pensions equality. Drawing on nationalist ideology, Guofeng believes that the interests of the state are higher than the interests of individuals, and that individuals should bolster the state. As a proponent of anti-American ideas, he expressed the belief that the state should spend more money on the military even at the expense of social welfare such as pensions. Nationalism motivated some middle-aged workers to dismiss inequalities in pension entitlements and even to despise those who protest against the such inequalities. They pitted their core value of nationalism as an argument against reforming the current pension arrangements. Guofeng's standpoint illustrates the impact of nationalist and resonates with Armeanu's (2010) argument that nationalism can be related to views on pensions:

For the people at my level, we are not like some other levels [people with lower incomes]. Of course, I am not discriminating against them. I mean, we cannot only care about ourselves and ignore others. . .you should consider the state... the Yankees still provoke us regularly. If our national defence declined, we might regress a century, right? So. . I I will obey the government; I will accept how much they give me. I will certainly not follow some people. . . [who]. . .protested in front of the government. I will certainly not take part [in such protests]. I may also do some propaganda for the government. Perhaps my voice is relatively weak, but my voice represents positive energy.

- Guofeng, male, 53, doctor

Shuli and Guofeng illustrate the views of those who are unwilling to see pension reforms, especially any reforms that might decrease their pensions in the future. According to Wenhua, a shop owner, criticism of protesting enterprise workers is not based on concerns over public interests but on privileged people's inclination to defend their privileges. She rejected the nationalist line of argument adhered to by Guofeng. Interestingly, although they held opposite opinions, both Guofeng and Wenhua claimed that people should try to understand the standpoints of others. Wenhua tended to consider the interests of enterprise workers who are suffering from unfairness while Guofeng argued on behalf of the state or what he considered represents the nation. Wenhua also attacked some elites who consider themselves superior and claim privileges even after retirement:

Oh, those who are full cannot know the feeling of those who experience hunger. (. . .) Humans should think of others, but some feel that since they started to work, they went to a better working unit, so they consider themselves better than others. But when they are retired, they are still better off than others. So, for them, really, they do not want to be the same as enterprise workers.

- Wenhua, female, 53, shop owner 
Different from the debates of the left and the right in most democratic countries, the main fault line concerning the pension policy in contemporary China illustrates the division between nationalist ideology and more redistributive logic. Divided by the discriminatory pension policy, the enterprise workers generally criticised current pension policy on equality grounds. Based on a nationalist ideology, the public-sector employees among the participants tended to think that enterprise workers are "selfish and do not consider the state" (Guofeng). The unequal pension policy catalyses such divisions.

Another strand of criticism directed by enterprise (private sector) workers against the public-sector employees pertained to what was seen as a large "army" of public officials whose incomes might have been modest but whose pensions were now comparatively generous in view of their small pension contributions:

Why the pensions are in debt in China? First, it's the massive public officials' army, right? Over 20 million public officials. . They used to receive relatively low pay in the past, the salaries of the public officials are indeed not high. . . but now they get high pensions, right?

- Wengu, male, 49, manager of an enterprise

Some expressed the view that pensions of public officials are increased surreptitiously, while even modest increases for enterprise-sector workers are accompanied by high-profile publicity:

Every year, when they increased the [enterprise sector] pensions, all kinds of newspapers are writing about it. . . But when they increase the pensions of public institutions employees, have you seen this in the news? They can get three or four thousand when they just retire. Have you seen this advertised? When the enterprise workers get extra tens of yuan, they advertise this around the whole country. But when they really raise the pensions dramatically for some people [employees in public sectors], there is no mention of this...

- Wenhua, female, 53, shop owner

Such views reflect the resentment that enterprise-sector employees and small business owners feel towards those who are entitled to public-sector pensions. Lack of transparent communication about changes in pensions adds to such resentment.

\section{Diverse retirement modes in urban China}

We will now turn to discussing the findings pertaining to the retirement modes in contemporary China which contrast with the rigidly fixed official retirement ages. Early retirement, working post-retirement and work without fixed retirement ages have become common in urban China. For instance, when retired at 45 - very young age compared with the official retirement age of 60 for men - Lianyu was happy with his early retirement and spent a lot of his time on housework and caring for family members since he was free from the pressure of paid employment:

I take care of my wife and my child. Also, my mum. . .she is 91 this year. (. . ) Buying vegetables and cooking, that is what I do. It is because in Shanghai, normally men do the housework at home.

- Lianyu, male, 55, retired enterprise worker

In contrast to Lianyu's choice, many others had chosen to work beyond their official retirement ages. For instance, Baocai worked for a few years after reaching his retirement age stated the following:

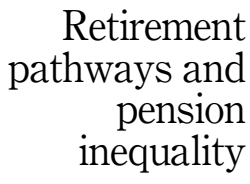


IJSSP

$41,13 / 14$

106

[In my work place there were] two or three generations of managers, they did not want me to retire. They said I'd better stay and help: we still lack good people like you. They required me to stay [as long as my] health situation was ok, and the department had the [need for my inputs]. After all, I was a member of the CCP [Communist Party], right? You need to obey the demands of the organisation, right?

- Baocai, male, 63, public official (returned to work after retirement)

Baocai specifically mentioned that a reason for him to remain working was his identity as a member of the CCP. In China, it is important for party members to remain loyal to their organisations as well as their "socialist" careers. Many members of the CCP would be willing to respond to the demands of the Party when summoned. This phenomenon occurred among some participants who were public officials, suggesting that the CCP still has some influence on the decisions of some mature workers to continue working beyond their official retirement.

What does retirement mean for older workers and the newly retired in China? We argue that there are two dimensions when people talk about retirement in contemporary China. The first dimension is the official retirement age of the enterprises or working units. When people reach the official retirement age or the retirement age of the working unit, they start to receive pensions. This transition can bring significant changes to some citizens, such as the enterprise workers who may suffer a major loss of income after they retire.

However, the influence of another dimension upon individuals also exists, namely the transition from working to a different, retired lifestyle. Different from the first one, this dimension is gauged by the individuals themselves instead of the working units or the establishment. They can deliberate whether to look for a new job after retirement and in some cases even when to stop working regardless of the retirement ages. At present, retirees in China can still receive their pensions if they choose to start a new job after retirement. The independence of the incomes from pensions and work encouraged some participants to look for post-retirement jobs. Some older workers draw down generous pensions and salaries at the same time, which further exacerbates the disparity of retirement incomes.

Furthermore, these two dimensions were well aligned for some participants. They kept working until they retired and enjoyed their later lives after reaching the official retirement age. The timing and conditions of working and retiring were clear for these respondents. For others, however, the transitions happened at less regular points in time. Some gave up work in their 40s (such as Lianyu who was quoted above). In contrast, others kept working into their 60s after reaching their official retirement ages (for instance Baocai). Also, there is an overlap between these two phenomena, as illustrated by Liyan. Not entirely happy with the retired lifestyle, she sought other work after retirement. She reflected on her fears regarding retirement and reasons for working beyond retirement:

I always think that the social security now, it is not as good as people think. You see I have many people living nearby; they are sick or something else, they spend all their savings [and] it may still not be enough. So now I feel that if I do not have the money to be old, to be sick, to seek medical support, it is like I cannot feel relaxed about the prospect of my life in retirement. I am now worrying, because you see the tuition fees of the child are rather high, or if the seniors are sick, the expenses would also be high. This makes it hard to imagine that ... I can survive if I am not able to work or have no income. I cannot imagine this situation. So, I am constantly wondering how I can do some work, have a stable income, maybe then I can afford my life in retirement.

- Liyan, female, 47, shop owner

For the individuals who have been or are currently in employment, the transitions in the second dimension would happen eventually. However, retirement in the first dimension may never happen to some people. This type includes the employer, the shop owners, the selfemployed and so on. Chunxian is the owner of a jade shop: he can work as long as he wishes. 
Covered by the urban resident pension system, he will get a small pension monthly when he reaches the formal retirement age. However, he envisaged continuing to work both due to the nature of his employment (it is not dependent on physical strength) and the stream of additional income it provides:

My job is not constrained by age; I can do this work as long as my body is still able to move. Maybe when I turn 80, if I am still well, I can carry on doing some things. . I may focus more on leisure and not put so much effort into running this shop. But. . . the later life requires some money... So, running this shop, why I chose to do this in my middle age, this career, because age is not very important in this job, unlike the jobs that require heavy labour, if I was really old, definitely I could not do those kinds of work.

Chunxian, male, 43, shop owner

Due to the retirement policy in present-day China, some middle-aged participants had retired rather early and enjoyed their retirement at a relatively young age. In contrast, usually driven by economic pressure, others chose to work beyond their retirement ages. Without an official retirement age, some workers such as the self-employed can be rather flexible in their working and retirement. Hence, there is no unified retirement pathway for all or even the majority of the citizens in present-day urban China.

Notwithstanding the diverse retirement modes in contemporary China, there are some structural factors regarding individuals' freedom on deciding their own retirement ages. The personal financial situation influences the degree of freedom in making decisions on the timing of retirement. Again, we detected differences between enterprise workers and the public sector. Having different scenarios of pension contributions and pension entitlements, employees of public institutions and public officials have obvious advantages over enterprise workers concerning their economic situations after retirement. Having the prospect of higher retirement incomes, public-sector workers felt they had more freedom in their retirement lives. Pension policies influenced the latitude that individuals had regarding work/retirement choices, again reflecting unequal pension entitlements.

Although the economic situations of the public-sector employees and retirees varied, none of the participants were living in poverty. Some public- sector employees chose to work beyond retirement, but in these cases non-financial factors such as commitment to and bonds with the working units were their primary reasons for the postponement of retirement. Constrained by the fixed official retirement ages, the employees of public institutions generally have limited scope to retire early even where they have a strong preference for retirement. In contrast, the choices of enterprise workers are more affected by their financial situation.

Economic inequality exists not only between the public sector and the private sector but also among the enterprise workers. Unlike among the public institution employees, financial situations varied significantly among the enterprise workers. For enterprise workers, financial considerations were the primary factor shaping their retirement decisions. Their work/retirement arrangements were generally more negotiable with their managers or employers, and their pension entitlements were relatively modest, creating incentives for staying in or returning to work. In the contemporary era, the rigidly fixed retirement policy no longer serves the diverse and individualised needs of urban workers in China. The current context of urban China requires a more flexible retirement policy, which would be better aligned with the diverse needs and wishes of middle-aged and older workers and retirees.

While space here prohibits us from marshalling more data, it is also important to point to a link between the family situations of the middle-aged and their choices on work/retirement. The needs of younger and older family generations are a factor that can influence the
Retirement pathways and pension inequality 
IJSSP

$41,13 / 14$

108

decisions of the middle-aged citizens on when to retire and whether to continue working. With the parents of many middle-aged workers still alive, they expressed concerns over the health status of their parents and the need to be available if called upon to help. Grandparents who face the transition to retirement have to balance between work/retirement choices and family (childcare) needs (Goh, 2009). Others were concerned about the incomes of younger family generations and wanted to be able to contribute to their household and educational expenses. This finding resonates with that of Bovenberg (2008), who argues that longer working lives can provide mature workers with the chance to support their children and also fulfil their career ambitions. As an alternative, retiring early or on time can provide middle-aged citizens with the opportunity to spend more time in supporting the younger generation with childcare.

\section{Conclusions}

The pension and retirement policy is the most significant reason for the inequality in later lives in contemporary China. By setting different criteria of pension entitlements between enterprise workers and public-sector employees, the pension policy in China generates significant inequality between different groups. Combined with the cumulative (dis) advantages of the individuals accrued over the life course, the discriminative policy arrangements make disparities in later lives inevitable (see also Hanewald et al., 2019). To work as an employee of a public institution is an advantage compared with those who work in enterprises. In terms of incomes, this advantage is not very obvious before retirement. However, the advantages of working in the public sector are magnified after retirement. In other words, the benefit of public-sector employees increases along with the life course, and the inequality in later lives becomes distinctive.

Public-sector employees - who can receive relatively high pension entitlements - are inclined to defend their privileges in pension entitlements. This phenomenon chimes with Armeanu (2010) who argues that influential opposition to the pension reform often comes from the groups who are benefiting from current pension arrangements. Although most participants in this group were aware of the inequality in retirement incomes, they were resistant to the idea that their benefits could be reduced. Their inclination to justify pension inequality resonates with the argument of O'Donnell and Tinios (2003) that opinions reflect the pension system. Notably, some employees in public institutions criticised those who protest against inequality in pensions (even though pension -related protests in China are rare at present).

The Confucian welfare state also plays a part in the maintenance of inequality in later lives (Abrahamson, 2017). Influenced by the Confucian tradition, families play an essential part in providing financial support and care for older adults. Despite the officially socialist polity of China, the problem of inequality in later lives is significant. As employees of the public sector, policymakers may have little interest in tackling inequalities in pensions and retirement. In fact, the Chinese government does not publish the details of spending on pensions. This lack of transparency illustrates the reluctance of policymakers to bring about greater equality in old-age incomes, which might be partly attributed to the influence of Confucian ideation where family continues to retain a central position of responsibility for its members' welfare.

The findings also point to a significant leeway between the official retirement ages, which are regulated by the government, and the actual retirement ages in China. Although the official retirement ages are relatively low, there are many workers who retire much earlier than the official retirement ages, through negotiations with their working units. Meanwhile, others choose to continue working or even look for other jobs after reaching their official retirement age. In addition, without a working unit, many citizens do not have a fixed retirement age, and their pathways to retirement are not regulated by the government. All these pathways illustrate the disparity between the government policies and the behaviours 
of individuals. The transitions to retirement are becoming increasingly individualised instead of collective or unified.

The diverse retirement modes are a reflection of the inequality in later lives in present-day China. While the collective and fixed transitions to retirement have weakened in urban areas of contemporary China, the disparity in later lives is not only related to the transformation of society and economy but also to elements of continuity, as manifested for instance in fervent nationalism and party loyalty that continue to motivate longer working lives for some. Inequality (in later lives) contributes to the diversity of transitions to retirement. The disparity between workers/pensioners under different pension systems and the variation among workers/pensioners under the same pension systems both add to the variety of retirement modes. Driven by the unequal pension policy, those inside the establishment (employees of the public sector) and those outside the establishment (enterprise workers and self-employed) have different situations and considerations regarding their transitions to retirement and differences that are likely to persist and become more pronounced in the absence of further extensive pensions reform in China.

\section{References}

Abrahamson, P. (2017), "East Asian welfare regime: obsolete ideal-type or diversified reality", Journal of Asian Public Policy, Vol. 10 No. 1, pp. 90-103.

Armeanu, O. (2010), “The battle over privileges and pension reform: evidence from legislative Roll Call analysis in Poland", Europe-Asia Studies, Vol. 62 No. 4, pp. 571-595.

Bakkeli, N.Z. (2020), "Older adults' mental health in China: examining the relationship between income inequality and subjective wellbeing using panel data analysis", Journal of Happiness Studies, Vol. 21 No. 4, pp. 1349-1383.

Bambra, C. (2007), "Going beyond the three worlds of welfare capitalism: regime theory and public health research", Journal of Epidemiology and Community Health, Vol. 61 No. 12, pp. 1098-1102.

Beland, D. and Yu, K. (2004), "A long financial March: pension reform in China”, Journal of Social Policy, Vol. 33 No. 2, pp. 267-288.

Bovenberg, A. (2008), "The life-course perspective and social policies: an overview of the issues", CESifo Economic Studies, Vol. 54 No. 4, pp. 593-641.

Cai, Y. and Cheng, Y. (2014), "Pension reform in China: challenges and opportunities", Journal of Economic Surveys, Vol. 28 No. 4, pp. 636-651.

Chang, K. and Song, M. (2010), "The stranded individualiser under compressed modernity: South Korean women in individualisation without individualism", The British Journal of Sociology, Vol. 61 No. 3, pp. 539-564.

Charmaz, K. (2014), Constructing Grounded Theory, 2nd ed., SAGE, London.

Conlon, C., Timonen, V., Elliott O'Dare, C., O'Keeffe, S. and Foley, G. (2020), "Confused about theoretical sampling? Engaging theoretical sampling in diverse grounded theory studies", Qualitative Health Research, Vol. 30 No. 6, pp. 947-959.

Ding, Q. and Hesketh, T. (2006), "Family size, fertility preferences, and sex ratio in China in the era of the one child family policy: results from national family planning and reproductive health survey", BMJ, Vol. 333 No. 7564, pp. 371-373.

Eklund, L. (2018), "Filial daughter? Filial son? How China's young urban elite negotiate intergenerational obligations", NORA-Nordic Journal of Feminist and Gender Research, Vol. 26 No. 4, pp. 295-312.

Esping-Andersen, G. (1990), The Three Worlds of Welfare Capitalism, Polity, London.

Feldstein, M. (1999), "Social security pension reform in China”, China Economic Review, Vol. 10 No. 2, pp. 99-107. 
IJSSP $41,13 / 14$

\section{0}

Fisher, K., Zhang, X. and Alston, M. (2018), "Shanghai aged care and Confucian welfare”, International Journal of Sociology and Social Policy, Vol. 38 Nos 9/10, pp. 722-735.

Flick, U. (2018), Doing Grounded Theory, 2nd ed., SAGE, London.

Fong, V. (2002), "China's one-child policy and the empowerment of urban daughters", American Anthropologist, Vol. 104 No. 4, pp. 1098-1109.

Frazier, M. (2004), "After pension reform: navigating the 'third rail' in China", Studies in Comparative International Development, Vol. 39 No. 2, pp. 45-70.

Goh, E. (2009), "Grandparents as childcare providers: an in-depth analysis of the case of Xiamen, China", Journal of Aging Studies, Vol. 23 No. 1, pp. 60-68.

Goulding, C. (1999), Grounded Theory: Some Reflections on Paradigm, Procedures and Misconceptions, working paper, University of Wolverhampton.

Hanewald, K., Jia, R. and Liu, Z. (2019), Why Is Inequality Higher Among the Old? Evidence from China, research working paper 2019/10, Australian Research Council Centre of Excellence in Population Ageing Research.

Hesketh, T., Lu, L. and Xing, Z. (2005), "The effect of China's one-child family policy after 25 years", New England Journal of Medicine, Vol. 353 No. 11, pp. 1171-1176.

Hinrichs, K. and Lynch, J. (2010), "Old-age pensions", in Castles, F. (Ed.), et al. (Eds), The Oxford Handbook of the Welfare State, Oxford University Press, Oxford.

Holliday, I. (2000), "Productivist welfare capitalism: social policy in East Asia", Political Studies, Vol. 48 No. 4, pp. 706-723.

Hu, N. and Yang, Y. (2012), "The real old-age dependency ratio and the inadequacy of public pension finance in China", Journal of Population Ageing, Vol. 5 No. 3, pp. 193-209.

Jones, C. (1993), "The Pacific challenge: Confucian welfare states", in Jones, C. (Ed.), New Perspectives on the Welfare State in Europe, Routledge, London, pp. 198-217.

Kwon, H. (2005), "An overview of the study, the developmental welfare state and policy reforms in East Asia", in Kwon, H. (Ed.), Transforming the Developmental Welfare State in East Asia, Palgrave Macmillan, New York, pp. 1-23.

Lee, D. (2018), "The evolution of family policy in South Korea: from Confucian familism to Neofamilism", Asian Social Work and Policy Review, Vol. 12 No. 1, pp. 46-53.

Lin, K. and Rantalaiho, M. (2003), "Family policy and social order-comparing the dynamics of family policy-making in Scandinavia and Confucian Asia”, International Journal of Social Welfare, Vol. 12 No. 1, pp. 2-13.

Liu, T. and Sun, L. (2016), "Pension reform in China", Journal of Aging and Social Policy, Vol. 28 No. 1, pp. 15-28.

Mercer (2019), Melbourne Mercer Global Pension Index, Monash Centre for Financial Studies, Melbourne.

O'Donnell, O. and Tinios, P. (2003), "The politics of pension reform: lessons from public attitudes in Greece", Political Studies, Vol. 51 No. 2, pp. 262-281.

OECD (2017), Pensions at a Glance 2017: OECD and G20 Indicators, OECD Publishing, Paris.

OECD (2019), China: Pension System in 2018, OECD Publishing, Paris.

Oxford Dictionaries | English (2017), Middle Age-Definition of Middle Age in English, Oxford Dictionaries, available at: https://en.oxforddictionaries.com/definition/middle_age (accessed 19 August 2017).

Prince, M., Lloyd-Sherlock, P., Guerra, M., Huang, Y., Sosa, A., Uwakwe, R., Acosta, I., Liu, Z., Gallardo, S., Guerchet, M., Mayston, R., Montes de Oca, Y., Wang, H. and Ezeah, P. (2016), "The economic status of older people's households in urban and rural settings in Peru, Mexico and China: a 10/66 INDEP study cross-sectional survey”, SpringerPlus, Vol. 5, p. 258. 
Salditt, F., Whiteford, P. and Adema, W. (2008), "Pension reform in China", International Social Security Review, Vol. 61 No. 3, pp. 47-71.

Song, Z., Storesletten, K., Wang, Y. and Zilibotti, F. (2015), "Sharing high growth across generations: pensions and demographic transition in China", American Economic Journal: Macroeconomics, Vol. 7 No. 2, pp. 1-39.

Retirement pathways and pension inequality

Timonen, V., Foley, G. and Conlon, C. (2018), "Challenges when using Grounded Theory: a pragmatic introduction to doing GT research", International Journal of Qualitative Methods, Vol. 17 No. 1, pp. 1-10.

West, L. (1999), "Pension reform in China: preparing for the future", Journal of Development Studies, Vol. 35 No. 3, pp. 153-183.

Yeh, C., Cheng, H. and Shi, S. (2020), "Public-private pension mixes in East Asia: institutional diversity and policy implications for old-age security", Ageing and Society, Vol. 40 No. 3, pp. 604-625.

Zhang, X. (2009), "Enterprise pensions in China: history and challenges", Public Finance and Management, Vol. 9 No. 1, pp. 76-96.

Zhu, H. and Walker, A. (2017), "The gap in social care provision for older people in China”, Asian Social Work and Policy Review, Vol. 12 No. 1, pp. 17-28.

\section{Corresponding author}

Virpi Timonen can be contacted at: timonenv@tcd.ie

For instructions on how to order reprints of this article, please visit our website:

www.emeraldgrouppublishing.com/licensing/reprints.htm

Or contact us for further details: permissions@emeraldinsight.com 